\title{
Economic Growth and Demographic Dividend Nexus in Nigeria: A Vector Autoregressive (VAR) Approach
}

\author{
Ademola Obafemi Young ${ }^{1}$ \\ ${ }^{1}$ Department of Economics, College of Humanities, Management and Social Sciences, Mountain Top University, \\ Prayer City, Ogun State, Nigeria \\ Correspondence: Ademola Obafemi Young. Tel: 234-806-982-0390. E-mail: aoyoung@mtu.edu.ng
}

Received: October 30, 2018

Accepted: November 22, 2018

Online Published: January 30, 2019

doi:10.5539/ass.v15n2p37

URL: https://doi.org/10.5539/ass.v15n2p37

\begin{abstract}
In demography and population economics discourse, the macroeconomic implications of an upsurge in working age population, notably the labour force, on economic growth has been widely studied and the inherent beneficial impact has become known as demographic dividend. However, the exact mechanism linking the dividend to growth remains a perennial question. This motivates the current study to investigate empirically the dividend-growth nexus in the context of Nigerian economy in a multivariate VAR model spanning between the period 1970 and 2017. Specifically, the paper attempted to answer the question: Is the Nigerian Demographic Dividend an Education-triggered Dividend? Innovation Accounting Techniques was applied to assess the dynamic interactions among the variables. The empirical evidence obtained revealed that the innovation in gross enrollment made much contribution to the variation in economic growth relative to innovation in economic support ratio. The magnitude ranges between 20.09 and 27.54 percent. This result, thus, lend credence to the theoretical view of the education-triggered dividend model which ascribes to education twofold roles of helping to lessen fertility and also enhancing productivity but invalidates the conventional dividend paradigm.
\end{abstract}

Keywords: VAR model, innovation accounting techniques, demographic dividend, demographic transition, economic growth, Nigeria

\section{Introduction}

Over the past three decades, in demography and population economics discourse, two strands of contentious theoretical literature analyzing the inherent beneficial impact of an upsurge in the labour force (i.e the working age population) on economic growth have evolved distinctly; specifically, the conventional demographic and education-triggered dividend models. On the one hand, the conventional demographic dividend model, which encompasses the works of Bloom and Freeman (1988); Higgins and Williamson (1997); Bloom and Sachs (1998); Mason (2001); Bloom, Canning and Sevilla (2001); and many others, advanced the proposition that, given output per worker, labour force participation rate, and unemployment rate, a rise in the share of the population concentrated in the working ages, particularly the labour force, will as a matter of simple algebra, lead to an increase in output per capita (Mason, 2005). Put differently, this theory avers that the falling shares of children in the overall population and the accompany increasing proportions of the population in the labour force, postulated to be exogenously triggered by declined in fertility (presumed to be a consequence of family planning programme), will inherently under certain conditions (such as investments in education and health, good governance, employment etc) bring about higher productivity and faster economic growth. A phenomenon known as demographic dividend.

On the other hand, the education-triggered dividend model, whose origin can be traced to Cuaresma, Lutz, and Sanderson (2014), premised on human capital theory, implicitly dismissed the conventional demographic dividend model's view. Essentially, in contrast to the conventional model, the observed nexus between the increase in labour force and higher productivity, according to the education-triggered dividend paradigm, results from the impacts of higher educational attainment on fertility and also, independently, on higher productivity (Cuaresma et al., 2014). Primarily, this strand of literature asserts that, firstly, human capital like physical capital is an important factor input which can be accumulated over time to increase the economy's productive potential (Issa, 2005; Arabi \& Abdalla, 2013). Secondly, human capital accumulation is intimately linked to other development phenomena such as demographic transition and income distribution (Issa, 2005; Arabi \& Abdalla, 
2013). The age-variation in labour supply and age-earning profiles, for instance, reflect life-cycle accumulation of human capital (Malmberg, 1994). Thus, according to this body of literature, the value of an additional worker in the economy varies by the extent of human capital dynamics and that as soon as the impact of human capital accumulation is controlled for, as argued in Cuaresma et al. (2014), evidence that an upsurge in the labour force, occasioned by demographic transition, affects labour productivity becomes insignificant. In essence, from a theoretical standpoint, the conventional and education-triggered dividend models differs as regards the principal force behind the demographic dividend.

On the empirical front, numerous studies have attempted to explore the empirical implications of these two propositions. While some studies (Bloom \& Williamson, 1998; Duryea \& Székely, 1999; Andersson, 2001; Bloom \& Canning, 2004; Kelley \& Schmidt, 2005; Mason, 2005; Fang \& Wang, 2005; Feyrer, 2007; Nguyen, 2008; Choudhry \& Elhorst, 2010; Wei \& Hao, 2010; Bloom et al., 2013; Zhang et al., 2015; Sarker, Khan, \& Mahmood, 2016; Misra, 2017; et al.) lent credence to the conventional dividend paradigm which views decline in fertility as an exogenous trigger for an increasing share of labour force and which under certain circumstances will lead to higher productivity and faster growth; several others (Krueger \& Lindahl, 2001; Kelley \& Schmidt, 2005; Babatunde \& Adefabi, 2005; Gyimah-Brempong, Paddison, \& Mitiku, 2006; Tiruneh \& Radvansky, 2010; Lee, 2010; Ghalandarzehi \& Safdarie, 2012; Akbari, Esfahani, \& Jouzaryan, 2012; Cuaresma, Lutz, \& Sanderson, 2014; Ogunniyi, 2017; Papakonstantinou, 2017; Kotásková et al., 2018; Ali, Egbetokun, \& Memon, 2018) lent credence to the education-triggered dividend model which ascribes to education the twofold roles of helping to lessen fertility and increasing productivity. In essence, in accordance with the theoretical discrepancies (see figure 1 in the appendix 1 adapted from Prskawetz, 2014), empirical evidences on the exact mechanisms linking the dividend to growth, as theorized by the two schools of thought revealed mixed outcomes.

Nigeria has continued to experience rapid labour force growth. As of 1970, for instance, it was estimated at 22.6 million (Adawo et al., 2012). Between 1990 and 2000, it rose from 30 million to 38.9 million (World Development Indicators, 2018). Furthermore, premised on National Bureau of Statistics (NBS) data set, it currently stands at 85 million in 2017 having risen from 72.9 million in 2014 to 77 million in 2015. In particular, it is expected to rise from 77 million in 2015 to 110 million in 2025 and 161 million in 2050 (Mariam et al., 2011; The Economist Intelligence Unit, 2015; NBS, 2018). In essence, like other countries around the world, Nigeria has indeed entered the demographic window of opportunity- an economic growth potential created by shifts in population age structure. As such, the critical question is this: Is the Nigerian Demographic Dividend an Education Dividend? This is because in designing and adopting appropriate policy for Nigeria, an in-depth understanding of the circumstances under which this favourable demographic situation is associated with economic growth is indispensable. Although, as section II highlights, ever since the issue of dividends began to unfold in the late 1990's, the literature is replete with empirical studies aimed at establishing the precise nexus between dividends and growth, however, the bulk of these studies focused on the European and Asian than African countries. In the case of Nigeria, while there is a sizeable literature (for instance, Agunwamba et al., 2009; Alao, 2010; Bloom et al., 2010; Guengant \& Kamara, 2012; Bloom et al., 2013; Reed \& Mberu, 2014; Aidi et al., 2016; Chisom, 2018) on demographic trends and their economic implications, however, the econometric evidence on the exact mechanisms linking the dividend to growth is still missing. This study, thus, will fill this gap. Following the introduction, the other sections of the study is arranged as follows: section two depicts a brief review of related literature. In section three the methodology adopted for the study was discussed. Section four analyzed and discussed the empirical results. Finally, section five concludes the study.

\section{A Brief Literature Review}

\section{Empirical Literature on Conventional Demographic Dividend}

The term "demographic dividend", first appeared in Bloom and Williamson's work (Van Der Ven, and Smits, 2011) to refer to the phase, during demographic transition, in which the number and share of population in working ages grows steadily relative to the number and share of population in non-working ages resulted in more rapid economic growth (Rentería, Souto, Mejía-Guevara, \& Patxot, 2016). During the period 1965-1990, focusing on East Asia's economic miracle, Bloom and Williamson (1998) showed that beyond the population's overall size, its age structure dynamics is of great economic significance. More importantly, the study revealed that once the inherent assumption of a constant age structure of the population is dropped, demography matters for economic growth. Following the Bloom and Williamson's (1998) pioneering work, numerous studies have explored the implications of this proposition.

Behrman, Duryea, and Székely (1999) presents evidence for major world regions and for the most populous countries in each region on associations between age structures of populations and selected economic outcomes. 
The results suggest that the variables considered follow clear age-related patterns, that the patterns differ by regions, and that the patterns differ with different policy regimes related to trade openness, domestic financial market deepening and macroeconomic volatility. The evidence is consistent with the possibility that some age structure shifts can provide favourable conditions for development. Apparently regions such as East Asia in recent decades have been able to benefit from this demographic opportunity. However, in others such as Latin America and the Caribbean -which is at the verge of experiencing the largest age structure shifts in the coming decades- creating an adequate economic environment to translate the opportunity into higher living standards for its population is a major challenge (Behrman et al., 1999).

Andersson (2001) in his study titled "Scandinavian Evidence on Growth and Age Structure" focuses on economic growth and investigates empirically the influence of age variables on growth. The focus here is on annual data and individual countries, namely Denmark, Finland, Norway, and Sweden. Estimations of a typical growth specification, augmented with age variables and other, more volatile, economic variables, are carried out, and results from these regressions seem to indicate that economic growth is indeed affected by the age distribution. The effect does not disappear when the specification is re-estimated using an instrumental variable estimator in order to correct for the potential endogeneity of the economic variables. Since the age variables are highly correlated with each other, experiments with ridge regressions are also made in order to mitigate the collinearity which obscures the results when all of the age variables are included in the regressions. The results of the empirical investigation in this study confirms the findings in the studies mentioned above that the age distribution is a significant variable in the determination of growth, and that this effect is discernible also when we consider shorter time-spans.

Similarly, Bloom and Canning (2004) undertakes a cross-country analysis from 1965 to 1995 . They find that a favourable age structure has a positive impact on income growth provided that the country has a high degree of openness to trade. Kelley and Schmidt (2005) regressed the rate of growth of per capita income on the rates of growth of total and working-age population, including both dependency effects and Solow effects (dilution of capital stock). The results obtained revealed that the rate of growth of the working-age population explained roughly 20 percent (\%) of the rate of growth of income per capita over the period 1960 to 1995 . Conversely, Mason (2005) contended that given a fixed output per worker, labour force participation and unemployment rates, an upsurge in the share of the working-age population will bring about an increase in per capita output.

Using a large panel of 87 countries, Feyrer (2007) also found a strong and significant correlation between changes in workforce age structure and growth in worker productivity, with movement into the 40-49 age group from any other age group being associated with higher worker productivity. Thi Nguyen (2008) empirically studied the effect of demographics on economic growth of Vietnam. The results obtained showed that Vietnam's demographics offer a great opportunity for the economy to enhance its economic growth. Based on the data from 70 countries over the period 1961 to 2003, Choudhry and Elhorst (2010) found that per capita GDP growth is positively related to the growth differential between the working-age population and the total population, and negatively related to child and old-age dependency ratios. Equally, Wei and Hao (2010) by separating the effects of youth and elderly dependency ratios on economic growth in China found that changes in age structure, particularly the large decline in the youth dependency ratio, account for approximately one-sixth of the provincial per capita GDP growth rate between 1989 and 2004

Bloom, Sevilla, Humair, Trussell and Rosenberg (2013) estimated the impact of family planning programs on per capita income that can arise via the demographic dividend (DD). Bloom, et al. (2013) also developed a model that was used to determine the impact of "meeting unmet need" (MUN) for modern contraceptive methods on fertility and the age structure. In addition, Bloom, et al. (2013) similarly estimated empirically the DD that has been observed in other countries, using a cross-country regression with panel data covering forty (40) years. Using the age structure projected by MUN and the empirical estimates of the DD, the study estimated the potential for additional economic growth in Kenya, Senegal and Nigeria and; found that in 2030, these countries can enjoy an increase in income per capita of eight to thirteen percent by meeting one-third of their unmet need for modern contraception and can enjoy a thirty-one to sixty-five percent higher per capita income by meeting all of the unmet need. By 2050, these ranges become thirteen to twenty-two percent and forty-seven to eighty-seven percent respectively.

Zhang, Zhang, and Zhang (2015) in the context of regional development in China, between 1990 and 2005, examined the economic growth implications of demographic age structure and found that changes in age structure, as depicted by shifts both in the size and internal demographic composition of the working-age population, are significantly correlated with provincial economic growth rates. Sarker, Khan, and Mahmood (2016) examined the relationship between age structure and economic growth in Bangladesh through 
co-integration and vector error correction model over the period 1990 to 2014. The Johansen co-integration tests indicate that all the variables are co-integrated with one co-integrating vector. The VECM long run causality model indicates that there is a long run causality running from gross domestic product (PPP) to labour force participation rate ( $\%$ of total population ages 15-64) and population ages 15-64 (\% of total). Equally, in the short run a causal relationship was found among the variables. Also, impulse response function and variance decomposition results suggests that labour force participation rate, total (\% of total population ages 15-64) as well as population ages 15-64 (\% of total) can explain the major variations. The implication of their findings suggest that in Bangladesh the growth of working age portfolio is likely to increase our economic growth in the long run. Misra (2017) investigated empirically the relationship between economic growth and demographic dividend using fixed effect model covering a period of 1990-2015. The results from regression equation exhibit that relationship between GDP growth rate and demographic dividend is positive thus, validating the hypothesis that demographic dividend has a positive impact on economic growth.

\section{Empirical Literature on Education-Triggered Demographic Dividend}

From the beginning, demographic dividends and education were linked together (Cuaresma, Lutz, \& Sanderson, 2014). For instance, in Bloom and Williamson's (1998) pioneer work, among the explanatory variables included in the study was the level of human capital accumulation, proxied by the log of the average years of post-primary schooling of the population 25+ years old, premised on data in Barro and Lee (1993). However, despite the fact that the results obtained showed that the education variable always had a positive and statistically significant coefficient, the importance of education dynamics to the East Asian economic phenomenon was not discussed in depth. In Bloom et al., (1998), the results for the human capital accumulation variable were only reported for ordinary least square regressions and not the instrumental variable.

In the same vein, by making a distinction between the productivity effect (the growth of output per person of working age) and translations effect (the growth of output per capita due to changes in the share of the working age population in the aggregate population), Kelley and Schmidt (2005) examined per capita growth in eighty-six countries (86) over four (4) time periods: 1960 to 1970, 1970 to 1980, 1980 to 1990, and 1990 to 1995 and found that demographic changes globally accounted for about twenty (20) percent of economic growth, with a greater influence seen in Asia and Europe (Cuaresma et al., 2014). The log of the average years of post-primary schooling for males $25+$ years old, a proxy for education variable, functioned as part of the productivity effect. However, in all their results, contrary to Bloom et al., (1998), the coefficient of the education variable was statistically insignificant. Krueger and Lindahl (2001); De la Fuente and Domenech (2006); Cohen and Soto (2007); Cuaresma, Lutz, and Sanderson (2014) among others argued that outliers in worldwide cross-country educational attainment data sets and the quality of such data can be attributed such lack of empirical support for the positive effects of human capital on economic growth.

Using Johansen Cointegration and Vector Error Model (VECM), during the study period 1970-2003, Babatunde and Adefabi (2005) empirically examined the significance of human capital for economic growth in Nigeria. In the study, two channels of education were identified. As regards the first channel, human capital is used as an independent factor of production and in the second channel; human capital affects economic growth through technology parameter. The results obtained revealed that there is a long run relationship between economic growth and education. And that a well-educated labour force significantly influence economic growth both as a factor in the production function and through total factor productivity.

Employing panel data over the 1960-2000 period, a modified neoclassical growth equation, and a dynamic panel estimator, Gyimah-Brempong, Paddison, and Mitiku (2006) empirically examined the impact of higher education human capital on economic growth in African countries and found that all levels of education human capital, including higher education human capital, have positive and statistically significant impact on the rate of growth of per capita income. In addition, the growth elasticity of higher education human capital was found to be twice as large as the growth impact of physical capital investment, approximately 0.09 . During the study period 1970-2010, applying vector auto regression (VAR) and Error corrections model (ECM), Bakare (2006) examined the growth implications of human capital investment in Nigeria and found that there is a significant institutional and functional relationship between economic growth and investments in human capital in Nigeria. In particular, the results revealed that for a one-percentage point decrease in human capital investment, 48.1 percent fall in the rate of growth in gross domestic output is induced in the long-run.

Tiruneh and Radvansky (2010) empirically investigated the extent to which investments in human capital accumulation may contribute to the growth dynamics of the European Union over the last decades. In order to address this, the study applied a panel data during the period 1995-2009. The authors used three different proxies 
for human capital accumulation: secondary school enrollment, labor force with primary, secondary and tertiary education and research and development expenditure. The results from a panel of European economies seem to suggest all the education variables have been significantly and positively related with per capita GDP growth rates. Using conditional dummy and education attainment for the population aged 15 and above in 1960, during the study period 1960-2000, Lee (2010) looked at the impact of education on economic growth of seventy-five (75) countries. The results obtained showed that education helps to accelerate growth in a cross-section of economies once continental dummies are being controlled for. Ghalandarzehi and Safdarie (2012), using the endogenous growth model proposed by Lucas (1988), found that, in Iran, human capital is a pre-requisite for development because the rate of economic growth and development depends not only on the quantity but also on the quality of labour force. In particular, they showed that a $1 \%$ increase human capital measured by the rate of enrollment into the University increases economic growth by $0.29 \%$. Similar results were obtained by Akbari, Esfahani, and Jouzaryan (2012).

The prior literature on the demographic dividend distinguishes two sorts of age structure effects on per capita economic growth, namely the accounting and productivity effects (Cuaresma, Lutz, \& Sanderson, 2012). On the one hand, income per capita automatically increases if the productivity of the working age population remains constant but the number of dependents decreases. This accounting effect does not reflect systematic changes in output per worker (Osberg \& Sharpe, 2001). The productivity effect occurs when increases in the proportion of the working age population increases the productivity of that population (Maestas, Mullen, \& Powell, 2016). This is assumed to happen for a number of reasons, including more rapid increases in the capital stock because of the pattern of life cycle saving and because of the reallocation of resources from child-rearing to market-oriented activities. Cuaresma, Lutz, and Sanderson (2014) shows that education expansions are able to account for the sizable productivity effects which past authors had claimed to be caused by age structure changes. The pure demographic dividend found in the new analysis is therefore reduced to a modest accounting effect, whose size is significantly smaller than that of the productivity changes caused by the investment in education.

Ogunniyi (2017) explored the relative impact of human capital formation on economic growth in Nigeria from 1981 to 2014. He found that a long run dynamic relationship exists between human capital formation and economic growth in Nigeria; and thus recommended that in order to achieve economic growth, policymakers should inter-alia increase not just the amount of expenditure made on the education sector, but also the percentage of its total expenditure accorded to the sector. Kotásková et al. (2018) argued that education plays a central and significant role in economic growth of India. In particular, their findings revealed that there is compelling evidence proving a positive connection between education levels and economic growth in India which might influence governmental actions and shape the future of India. Using data for 132 countries over 15 years, Ali, Egbetokun, and Memon (2018) found that human capital plays a positive role in per capita GDP growth only in the presence of better economic opportunities and high-quality legal institutions. In fact, economic opportunities reinforce the effect of human capital on growth: the easier it is to do business and trade domestically or internationally, the stronger the effect of human capital on growth.

In sum, from the review of literature above, in explaining dividend-economic growth nexus the conventional and education-triggered dividend models differs as regards the principal force behind the demographic dividend (see models $\mathrm{A}$ and $\mathrm{B}$ in figure 1 in the appendix 1). Moreover, as the issue of dividends began to unfold in the late 1990's, empirical studies are more prominent in the European and Asian countries than Africa, which makes scanty the literature on the interactions between demographic dividends and economic growth that focus on developing world. In the case of Nigeria, while there is a sizeable literature on demographic trends and their economic implications (for instance, Agunwamba et al., 2009; Alao, 2010; Bloom et al., 2010; Guengant \& Kamara, 2012; Bloom et al., 2013; Reed \& Mberu, 2014; Aidi et al., 2016; Chisom, 2018), the econometric evidence for the growth impact of the demographic dividends is limited. This study, thus, will fill this gap.

\section{Materials and Method}

\section{Model Specification}

Following Bloom, Canning and Malaney $(1999,2000)$, this study adopts the theoretical framework of neoclassical growth model and specifies a Cobb Douglas production function as follows

$$
Q=\Omega \mathrm{P}^{\alpha} L^{1-\alpha}
$$

where $\Omega, P, \alpha, L$, and $Q$ are total factor productivity (or multi-factor productivity), physical capital stock, elasticity of output with respect to capital, labour force, and aggregate output respectively. Suppose the endogenous processes that generate physical capital accumulation and total factor productivity converge to a 
steady state, then the steady state output per worker $\left(q^{*}\right)$ is derived as follows

$$
\left(\frac{Q}{L}\right)^{*}=\Omega\left(\frac{P^{*}}{L}\right)^{\alpha} \Rightarrow q^{*}=\Omega p^{* \alpha}
$$

Conversely, suppose the steady state output per worker $\left(q^{*}\right)$ is determined by a set of variables, $\Psi$, that may influence total factor productivity and capital accumulation,

$$
q^{*}=\Psi \beta
$$

Where

$q^{*}=$ steady state output per worker,

$\Psi=$ matrix of variables influencing the steady-state level, and

$\beta=$ vector of parameters respectively.

Given the model (3), the regression equation derived, as specified by Bloom et al, (1999, 2000), assumes that an economy's rate of growth is proportional to its initial distance from its steady-state income level. That is,

$$
g_{y}=\Phi\left(q^{*}-q\right)
$$

where $\Phi$ and $q$ depict the rate of convergence and natural log of the initial per worker output respectively, $q^{*}$ is as previously defined. By combining equation (3) with the adjustment process (that is, equation 4a) and adding an error term $\varepsilon$ the study obtains equation (4b) whose parameters can be estimated as follows:

$$
g_{y}=\Phi\left(q^{*}-q\right)=\Phi \Psi \beta-\Phi q+\varepsilon
$$

Following Bloom and Canning (2003) and Thakur (2012), in order to obtain output per capita (which is a better indicator of the overall welfare for a country) equation (4b) is further transformed from output per worker to output per capita as follows

$$
\frac{Q}{N}=\frac{Q}{L} \frac{L}{N}
$$

where $Q, N$ and $L$ represent the aggregate output, the entire population, and the labour force respectively. Taking natural logarithm of both sides of equation (5)

$$
\begin{aligned}
\ln \left(\frac{Q}{N}\right) & =\ln \left(\frac{Q}{L}\right)+\ln \left(\frac{L}{N}\right) \\
p & =q+\ln \left(\frac{L}{N}\right) \\
q & =p-\ln \left(\frac{L}{N}\right)
\end{aligned}
$$

By combining equations (4b) and (8) the rate of growth of income per worker can be expressed as

$$
g_{y}=\Phi\left[\Psi \beta-p+\ln \left(\frac{L}{N}\right)\right]+\varepsilon
$$

Recall that, from the identity in model (5), the growth rate of per capita income is the addition of the growth rate of income per worker and the growth rate of labour force less the rate of growth of the population expressed as follows:

$$
g_{p}=g_{y}+g_{\text {labourforce }}-g_{\text {population }}
$$

By substituting (9) into (10), we then obtain a growth equation for per capita income as a function of initial income per capita, demographic factors and other variables affecting human productivity.

$$
g_{p}=\Phi\left(\Psi \beta-p+\ln \left(\frac{L}{N}\right)\right)+g_{\text {labourforc e }}-g_{\text {population }}+\varepsilon
$$


Hence, an econometric representation of equation (11) is given below:

$$
g_{p}=\alpha_{0}+\alpha_{1} p+\alpha_{2} \ln \left(\frac{L}{N}\right)+\alpha_{3} g_{\text {labourforce }}+\alpha_{4} g_{\text {population }}+\alpha_{5} \Psi+\varepsilon
$$

Equation (12) will thus form the base of our empirical strategy. To close the model there is the need for variables in vector $\Psi$ to be defined. As noted in the literature the usual variables generally included in the vector $\Psi$ are average years of secondary schooling, gross capital formation, a measure of trade openness and institutional quality, life expectancy, and geographic variables. Following the previous literature, equation (12) is thus modify by taking into account the objective of the study and thereby augmented by inserting human capital accumulation proxied by total school enrollment (i.e. gross enrollment). The argument is that higher level of human capital accumulation speeds up the adoption of foreign technology that is expected to balance the knowledge gap between the developed and the developing countries. Conversely, rate of natural increase, government policy on duration of education, minimum working age, dependency ratio, working age population, are some of the potential factors identified in the literature as influencing labour force dynamics (i.e. labour force growth and contraction). Thus, for simplicity in this study the labour force dynamics will be proxied by the rate of growth of the share of working aged population. Premised on these arguments, thus, equation (12) is augmented as follows:

$$
g_{p}=\alpha_{0}+\alpha_{1} p+\alpha_{2} \ln \left(\frac{L}{N}\right)+\alpha_{3} g_{\text {labourforce }}+\alpha_{4} g_{\text {population }}+\alpha_{5} \ln (G E R)+\varepsilon
$$

The basic premise of equation (13) is that health care and education of workers ensure greater productivity. Hence, an econometric representation of equation (13) is given below:

$$
\partial \ln P C R_{t}=\delta_{0}+\delta_{1} \ln P C I_{t}+\delta_{2} \ln E S R_{t}+\delta_{3}\left(\partial \ln W A P_{t}\right)+\delta_{4}\left(\partial \ln P O P_{t}\right)+\delta_{5} \ln G E R_{t}+\varepsilon_{t}
$$

where $\partial \ln P C R_{t}, \ln P C I_{t}, \ln E S R_{t},\left(\partial \ln W A P_{t}\right),\left(\partial \ln P O P_{t}\right), \ln G E R_{t}$, and $\varepsilon_{t}$ are rate of growth of income per capita, rate of growth of income/output per worker, economic support ratio, growth rate of working age population, growth rate of population, gross enrollment (proxied for human capital accumulation) and white noise residual respectively.

\section{Sources of Data and Definition of Variables}

As discussed in the preceding section, this study considered human capital accumulation (proxied by gross enrollment), economic support ratio, labour force dynamics, output per worker growth rate, and population growth rate as key determinants of real GDP per capita growth. The specific sources for each variable and measurements of the data employed in the study are depicted in Table 11 in appendix II. The data were sourced majorly from the publications of Central Bank of Nigeria Statistical Bulletin (2018), Penn World Table, version 9.0, Africa Development Indicators (2018), and World Development Indicators (2018).

\section{Estimation and Techniques of Analysis}

\section{Unit Root Test}

The Autoregressive Distributed Lag Bounds testing procedure to cointegration and the TYDL approach to causality, though, do not require pre-testing of the variables included in the model, however testing for unit root is indispensable for two key reasons: to avoid spurious regression problem and to select $d_{\max }$ (i.e. the maximum likely order of integration of the series). To this end, the Phillips Perron (PP) and the Augmented Dickey-Fuller (ADF) tests were applied. The choice of these two test statistics is informed by the fact that both tests control for higher-order autocorrelation. Both tests statistics were done for two alternative specifications at $5 \%$ level of significance. On the one hand, it was tested with intercept but no trend, and on the other hand, it was tested with both intercept and trend.

\section{Cointegration Test: ARDL Bound Testing Procedure}

Econometric literature proposes different methodological alternatives to empirically analyse the long-run relationships and dynamics interactions between two or more time-series variables (Esso \& Yaya, 2010). The most extensively used approaches, as argued by (Esso \& Yaya, 2010), include the maximum likelihood-based approach due to Johansen and Juselius (1990) and Johansen (1992) and the two-step procedure of Engle and Granger (1987). All these methods require that the variables under investigation are integrated of order one (Engle \& Granger, 1987; Juselius, 1990; Johansen, 1992; Muhammed et al., 2011). However, these tests suffer from low power and do not have good small sample properties (Cheung \& Lai, 1993; Harris, 1995; Muhammed 
et al., 2011). Owing to these difficulties, in this study, this study made use of the newly developed approach to cointegration. This technique is built on the estimation of an Unrestricted Error Correction Model (UECM hereafter) which enjoys numerous advantages over other cointegration techniques. For instance, Bounds testing procedure generally provides unbiased estimates of the long-run model and valid t-statistic even when some of the regressors are endogenous (Harris \& Sollis, 2003; Odhiambo, 2007, 2010; Mustafa \& Selassie, 2016). Besides, Inder (1993) and Pesaran and Pesaran (1997) have shown that the inclusion of the dynamics may correct the endogeneity bias (Yue, 2010). In addition, as argued by Hundie (2014), once the orders of the lags in the ARDL model have been appropriately selected, we can estimate the cointegration relationship using a simple Ordinary Least Square (OLS) method (Mustafa \& Selassie, 2016).

In view of the aforesaid advantages, the augmented form of the model (14) earlier specified is expressed as:

$$
\begin{aligned}
\Delta(\partial \ln P C R) & =\theta_{0}+\sum_{i=1}^{p} \theta_{1 i} \Delta\left(\partial \ln P C R_{t-i}\right)+\sum_{i=0}^{q} \theta_{2 i} \Delta \ln P C_{t-i}+\sum_{i=0}^{m} \theta_{3 i} \Delta \ln E S R_{-i}+\sum_{i=0}^{n} \theta_{4 i} \Delta\left(\partial \ln W A P_{t-i}\right)+\sum_{i=0}^{l} \theta_{5 i} \Delta\left(\partial \ln P O P_{t-i}\right)+\sum_{i=0}^{v} \theta_{6 i} \Delta \ln G E R_{t-i} \\
& +\delta_{1}\left(\partial \ln P C R_{t-1}\right)+\delta_{2} \ln P C C_{t-1}+\delta_{3} \ln E S R_{t-1}+\delta_{4}\left(\partial \ln W A P_{t-1}\right)+\delta_{5}\left(\partial \ln P O P_{t-1}\right)++\delta_{6} \ln G E R_{t-1}+\varepsilon_{1 t}
\end{aligned}
$$

where, $\theta_{0}, \Delta$ and $\varepsilon_{1 t}$ denote the drift component, first difference operator, and error term respectively. Accordingly, to apply cointegration tests the paper tested the null hypothesis $H_{0}: \delta_{1}=\delta_{2}=\delta_{3}=\delta_{4}=\delta_{5}=\delta_{6}=0$ of no cointegration, against the alternative hypothesis $H_{1}: \delta_{1} \neq \delta_{2} \neq \delta_{3} \neq \delta_{4} \neq \delta_{5} \neq \delta_{6} \neq 0$. However, before the cointegration test was applied, it was necessary to choose the apt lag length in order to avoid the problem of misspecification and loss of degree of freedom. Hence, following the literature, VAR lag order selection criteria attributed to Akaike information criteria (AIC), Log Likelihood (LL), Hannan-Quinn information criteria (HIC), Final Prediction Error (FPE), and Schwarz information criteria (SIC) criteria were employed.

\section{The Toda-Yamamoto and Dolado-Lutkepoh Approach to Causality Test}

Given the model (14) econometric literature proposes, contingent on time-series features of variables, three distinct methodological alternates to empirically analyze the dynamics interactions between two or more time-series variables, namely, a VAR Model in the level data, a VAR model in the first-differenced data, and a vector error correction model (Hundie, 2014). However, VAR estimation, as argued by Toda and Philips (1993 and 1994), often contains nuisance parameters. Besides, there is no acceptable basis for mounting a statistical test of causality test as the F-test statistic does not have a standard distribution when variable are integrated (Toda \& Philips, 1993 and 1994; Hundie, 2014). Correspondingly, the vector error correction model approach which involves pre-testing through unit root and cointegration tests suffers from size distortions and often can lead to mistaken conclusions about causality (Alimi \& Ofonyelu, 2013; Hundie, 2014). Thus, in this study following Hundie (2014), the TYDL approach to causality is adopted.

This technique has many advantages over other techniques. To start with, the approach is applicable regardless of cointegration and integration features of model. Second, it better controls the types I error probability (Hundie, 2014). Besides, when compared to VECM and VAR, as argued by Hundie, (2014), the simulation results by Yamada \& Toda (1998) show that among the three causality procedures, it is the most stable approach. The basic ideas behind the TYDL is to augment the correct VAR order, $p$, with, the maximum likely order of integration ( $\mathrm{d}_{\max }$ extra lags) of the series in the system. Thus, the augmented version of equation (14) is as follows:

$$
\left[\begin{array}{l}
\partial \ln P C R_{t} \\
\ln P C I_{t} \\
\ln E S R_{t} \\
\partial \ln W A P_{t} \\
\partial \ln P O P_{t} \\
\ln G E R_{t}
\end{array}\right]=\left[\begin{array}{l}
\alpha_{0} \\
\beta_{0} \\
\lambda_{0} \\
\eta_{0} \\
\sigma_{0} \\
\rho_{0}
\end{array}\right]+\sum_{i=1}^{p}\left[\begin{array}{l}
\alpha_{1 i} \alpha_{3 i} \alpha_{5 i} \alpha_{7 i} \alpha_{9 i} \alpha_{11 i} \alpha_{13 i} \\
\beta_{1 i} \beta_{3 i} \beta_{5 i} \beta_{7 i} \beta_{9 i} \beta_{11 i} \beta_{13 i} \\
\lambda_{1 i} \lambda_{3 i} \lambda_{5 i} \lambda_{1 i} \lambda_{9 i} \lambda_{11 i} \lambda_{13 i} \\
\eta_{1 i} \eta_{3 i} \eta_{5 i} \eta_{7 i} \eta_{9 i} \eta_{11 i} \eta_{13 i} \\
\sigma_{1 i} \sigma_{3 i} \sigma_{5 i} \sigma_{7 i} \sigma_{9 i} \sigma_{11 i} \sigma_{13 i} \\
\rho_{1 i} \rho_{3 i} \rho_{5 i} \rho_{7 i} \rho_{9 i} \rho_{11 i} \rho_{13 i}
\end{array}\right]\left[\begin{array}{l}
\partial \ln P C R_{t-i} \\
\ln P C I_{t-i} \\
\ln E S R_{t-i} \\
\partial \ln W A P_{t-i} \\
\partial \ln P O P_{t-i} \\
\ln G E R_{t-i}
\end{array}\right]+\sum_{j=p+1}^{P+d_{\max }}\left[\begin{array}{l}
\alpha_{2 j} \alpha_{4 j} \alpha_{6 j} \alpha_{8 j} \alpha_{10 j} \alpha_{12 j} \alpha_{14 j} \\
\beta_{2 j} \beta_{4 j} \beta_{6 j} \beta_{8 j} \beta_{10 j} \beta_{12 j} \beta_{14 j} \\
\lambda_{2 j} \lambda_{4 j} \lambda_{6 j} \lambda_{8 j} \lambda_{10 j} \lambda_{12 j} \lambda_{14 j} \\
\eta_{2 j} \eta_{4 j} \eta_{6 j} \eta_{8 j} \eta_{10 j} \eta_{12 j} \eta_{14 j} \\
\sigma_{2 j} \sigma_{4 j} \sigma_{6 j} \sigma_{8 j} \sigma_{10 j} \sigma_{12 j} \sigma_{14 j} \\
\rho_{2 j} \rho_{4 j} \rho_{6 j} \rho_{8 j} \rho_{10 j} \rho_{12 j} \rho_{14 j}
\end{array}\right]\left[\begin{array}{l}
\partial \ln P C R_{t-j} \\
\ln P C I_{t-j} \\
\ln E S R_{t-j} \\
\partial \ln W A P_{t-j} \\
\partial \ln P O P_{t-j} \\
\partial \ln G E R_{t-j}
\end{array}\right]+\left[\begin{array}{l}
\varepsilon_{1 t} \\
\varepsilon_{2 t} \\
\varepsilon_{3 t} \\
\varepsilon_{4 t} \\
\varepsilon_{5 t} \\
\varepsilon_{6 t}
\end{array}\right]
$$

Hereafter, following TYDL procedure, the study then estimated the augmented VAR model (16) by carrying out Block Exogeneity Wald test at 5 percent level of significance. If the null hypotheses $\alpha_{5 i}=0$, and $\alpha_{11 i}=0$ are rejected, then it is concluded that economic support ratio and gross enrollment (proxies for first demographic dividends) are Granger cause of economic growth, respectively. Correspondingly, the rejection of the null hypothesis of $\alpha_{5 i}=\alpha_{1 \mathrm{i}}=0$ denotes that gross enrollment and economic support ratio jointly Granger cause 
economic growth. Besides, if the null hypothesis of $\eta_{9 i}=0$ is rejected, then it is concluded that there is Granger causality from population growth rate to labour force dynamics. Equally, the rejection of the null hypothesis of $\lambda_{9 i}=0$ implies that there is Granger causality from population growth to support ratio. Furthermore, on the one hand the rejection of the null hypothesis of $\alpha_{0 i}=0$ implies that causality runs from population growth to economic growth. Similarly, on the hand if the null hypothesis of $\sigma_{1 i}=0$ then it is concluded that causality runs from economic growth to population growth rate. Consequently, implying bi-directional causality. Finally, the rejection of the null hypothesis of $\alpha_{h i}=0$ implies that causality runs from labour force dynamics to economic growth.

\section{Variance Decomposition and Impulse Response Function: Innovation Accounting Techniques}

Since the cointegration analysis focuses on the long-run properties of the macroeconomic model and more so Granger-causality may not tell us the complete story about the interactions among the variables of a system (Rajasekar, Deo, \& Ke, 2014), it is important to combine it with some additional information on how the long-run relations respond to shocks (Pesaran \& Pesaran, 2009). As such, to provide further insight into the dynamic interactions among the variables of the system, variance decomposition and impulse response function were carried out. While the impulse response functions (IRFs hereafter) allow ones to trace out the responsiveness of the endogenous variables in the VAR to shocks to each of the variables (Asmah, 2013), the variance decompositions (VDC hereafter) give the proportion of the movements in the endogenous variables that are due to their 'own' shocks, versus shocks to the other variables (Asmah, 2013; Mireku, Sakordie, \& Poku, 2013). Finally, in order to check the adequacy of the VAR models, various formal analytic tests such as autocorrelation, non-normality, heteroscedasticity and stability tests were conducted.

\section{Estimation and Discussion of Results}

\section{Unit Root Result}

Before detailed analysis of the variables were undertaken the study established the stationarity of the data. As it is depicted in Tables 1 and 2 presented in appendix II, the results revealed that $\partial \ln P C R_{t}, \ln P C I_{t}, \ln E S R_{t}$, $\left(\partial \ln W A P_{t}\right),\left(\partial \ln P O P_{t}\right)$, and $\ln G E R_{t}$ are stationary at first difference implying that $d_{\max }$ in the system is one (1).

\section{VAR Lag Order Selection Results}

A vital element in the specification of VAR models is the determination of the lag length of the VAR (Ozcicek, and McMillin, 1999). Braun and Mittnik (1993) argued that IRF and VDC derived from the estimated VAR are inconsistent when the lag length differs from the true length (Ozcicek \& McMillin, 1999). Moreover, as argued in Lutkepohl (1993), over fitting ( that is by selecting a higher order lag length than the true lag length) causes an increase in the mean-square forecast errors of the VAR and that under fitting the lag length often generates autocorrelated errors which results in inconsistent estimate (Ozcicek \& McMillin, 1999). Consequently, to choose the appropriate lag length, the VAR lag order selection criteria attributed to Schwarz information criteria, Final Prediction Criteria, Hannan-Quinn information criteria, Akaike information criteria, and Log Likelihood were considered were considered. Therefore, as depicted in Table 3 in appendix II, the optimal lag length $p$ is four.

\section{Cointegration Test Results}

The results of cointegration test, using ARDL Bounds Testing procedure, among the variables is depicted in Table 4. As can be seen from the result presented in Table 4 in appendix II the calculated F-statistic (10401.78) of the Wald-test is higher than upper bond critical value of (3.79) at five (5) per cent level of significance, implying that the variables are cointegrated.

\section{TYDL Causality Test Results}

As it is depicted in Table 5 in Appendix II, there is an evidence of a unidirectional causality from economic support ratio (a proxy for conventional demographic dividends) to economic growth. To be specific, the null hypothesis of no causal nexus between support ratio and growth, running from economic support ratio to economic growth is rejected. Conversely, the null hypothesis of no causal link between gross enrollment (a proxy for education-triggered dividend) and economic growth (proxied by income per capita growth), running from gross enrollment to economic growth is rejected. Further, in testing for a joint causal relationship between economic support ratio, gross enrollment, and per capita real GDP growth rate, the result showed that both support ratio and enrollment into institutions granger cause per capita real GDP growth rate in Nigeria implying that both human capital accumulation and economic support ratio were enormously important to economic growth process in Nigeria during the period of study. Hence, premised on TYDL causality test procedure, the empirical results obtained support both the conventional as well as the education-triggered dividends models. 
Moreover, according to the results depicted in Table 5 in Appendix II, population growth rate Granger cause both labour force dynamics proxied by growth rate of working age population and demographic dividends proxied by economic support ratio. This result is implied that population growth has the potentials of fostering economic growth in Nigeria. Aside the fact that it provides a huge base of labour force, an increasing population connotes an increase in the number of working population who can function as active participants in the course of the nation's economic growth and development. More importantly, labour force equipped with proper education, training, balanced health facilities and assisted by necessary tools and implements, is the greatest productive asset of nations. Furthermore, as can be seen from the TYDL causality test procedure results presented in Table 5 (in Appendix II) there exists a bi-directional causality between income per capita growth (proxy for economic growth) and population growth rate at 0.05 level of significance. Hence, causality runs in both directions thus implies the presence of a mutually reinforcing relationship between income per capita growth and population growth rate. Similar results were obtained in Thuku, Gachanja, and Obere (2013) for the case of Kenya.

Additionally, as reported in Table 5 in Appendix II the results provide evidence of a unidirectional causality running from growth rate of working age population, a proxy for labour force dynamics, to economic growth. In essence, an increase in labour force apparently brings about potentials for economic growth. Hence, premised on this result, Nigeria needs to strengthen the employability of the existing working-age population with continuous and remedial education, labour insertion programs and social assistance. More importantly, the this study suggests that there is the need for government to balance the need for immediate job creation solutions with investments in people's long term development and potential, beginning from a young age. This result corroborates the empirical findings of Jajri and Ismail (2010), Raleva (2014), and Hundie (2014).

\section{Impulse Response Function}

As stated earlier, Granger-causality may not tell us the complete story about the interactions between the variables of a system (Rajasekar et al, 2014), hence, to further investigate the dynamic interaction among $\partial \ln P C R_{t}, \ln P C I_{t}, \ln E S R_{t},\left(\partial \ln W A P_{t}\right),\left(\partial \ln P O P_{t}\right)$, and $\ln G E R_{t}$, the study generated IRFs which allow us to trace temporal responses of a variable to own shocks and shocks in other variables. In this instance in particular, from the IRFs we assessed the direction, magnitude and persistent of economic growth responses to innovations in labour force dynamics, economic support ratio and gross enrollment over ten years to enable us capture both the short term and long term responses using the Cholesky decomposition. The IRF analysis results are presented in figure 2 in Appendix I. In the first horizontal segment of figure 2 in Appendix I, we see the response of economic growth to itself and labour force dynamics. As regards the response of economic growth to innovation occasioned by its own shock it is observed that the response therein was positive from the first period, reaching its peak in the sixth period and declined gradually but still positive beyond the tenth period. Similar results were obtained in Hundie (2014). Moreover, as can be seen from figure 2 in Appendix I, a one standard deviation shock to labour force dynamics proxied by rate of growth of working age population did not have any effect on economic growth in the first year. Thereafter, economic growth maintained a positive response to shock in labour force dynamics. For instance a positive response of 0.54 percent in the second period continuously increase positively to $1.38,1.54$, and 1.68 in the third, fourth and fifth period respectively and thereafter maintained a steady positive increase of 0.7 percent till the end of the tenth year. This finding is consistent with the Granger causality test. Hence, labour force plays a crucial role in Nigeria's economic growth.

The second segment revealed the response of economic growth to economic support ratio (a proxy for conventional demographic dividends) and gross enrollment (a proxy for education-triggered demographic dividends). In response to a one standard deviation shock to economic support ratio, it was observed that economic growth declined by -0.07 percent in the first year and this continued thereafter to $-0.09,-0.08,-0.02$ and 0.03 percent in the third, fifth, seventh and ninth years respectively approaching zero in the tenth year. On the other hand, in response to a one standard innovation shock to gross enrollment, economic growth did not produce any effect in the first year. Economic growth began to respond positively to shock to gross enrollment from the second and third year as a unit shock to gross enrollment resulted to an increase in economic growth by 1.57 percent in the fourth year. Thereafter economic growth maintained a positive response to shock to gross enrollment all through the periods. The implications of the above findings therefore suggests that although the quantity of human capital (labour force), particularly economic support ratio, is an important determining factor of economic growth in Nigeria, investment in human capital formation need to be accorded high priority. Thus, as Nigeria is aspiring to be among the 20 leading economies in the world by the year 2020 , more importantly, as the global economy shifts towards more knowledge-based sectors, investment in human capital formation need to be accorded high priority because a nation's competitiveness in the New International Economic Order (NIEO) is strongly connected to the quality of her labour force. 


\section{Variance Decomposition}

This section of the study discusses the results of the forecast error variance decomposition. This analysis provides additional insight into historical relationships as it indicates the percentage of a variable's deviation from its forecasted value that was attributed to another variable. The VDC analysis results are presented in Tables 6-9 Appendix II.

An examination of forecast error variance decomposition of per capital real GDP growth in table 6 in Appendix II showed that all the variations in economic growth were due to its own shocks at 100 percent in the first year. However, the variations of own shocks in economic growth reduced to 58.69 percent in the second year. In the third year the variations reduced to 29.84 percent and continued to reduce as the forecasting horizon increased. After the fifth year, it marginally decreased to 13.0 and was almost stable at 13.0 percent. However, the situation is different from period two to period ten as in innovation in labour force dynamics contribution as a source of forecast error variance of per capital real GDP growth rate rose from 6.9 percent to 40.9 percent. A further observation of the variance decomposition results presented in table 6 in Appendix II revealed that the innovation in gross enrollment made much contribution to the variance in per capital real GDP growth rate relative to innovation in economic support ratio. The magnitude range between 20.09 and 27.54 percent. Overall, the result also corroborates that of the preceding section in that it clearly indicates that gross enrollment is a very crucial channel through which human capital accumulation could impact positively on economic growth in Nigeria. But for population growth rate the magnitude of its impact is very low and almost stable throughout the time horizon except for the first period. In sum, both impulse response analysis and forecast error variance decompositions results lend credence to the theoretical view of the education-triggered demographic dividend model which ascribes to education the twofold role of helping to bring down fertility and improving productivity.

An observation of the results of the variance decomposition in Table 7 revealed that labour force dynamics explained about 50 percent forecast error variation in its own shocks for all the periods, stating from 96.5 percent in the first period to 57.6 percent in the tenth period. Besides, the proportional contribution in itself, gross enrollment has the second largest effect which ranges from 3.2 percent in the second period to 12.0 percent in the tenth period horizon. The percentage that was attributable to shocks in economic growth rate was shown to be very close to population growth rate ranging from 1.5 to 10.3 and 1.9 to 11.0 percent respectively. The percentage contribution of economic support ratio was minimal ranging 2.3 to 9.1 percent.

Table 8 shows that the largest variation in the forecast error of economic support ratio arises from labour force dynamics which account for about 96.8 percent in the first period and 45.15 percent in the tenth period; while gross enrollment which is the second largest source of variation in economic support ratio contributes 16.65 and 23.4 percent in the third and tenth period respectively. Further, the variation of forecast error in gross enrollment due to per capita real GDP growth rate was very strong in that it contributes about 20 percent in the tenth period. Consequently, the forecast error variance of the economic support ratio by its own innovation is lower compared to those explained by the labour force dynamics, gross enrollment, and per capita real GDP growth rate. On the other hand, the percentage contribution of population growth rate was very minimal ranging from 0.7 percent in the first period to 2.1 percent in the tenth period.

Also, Table 9 depicts the proportion of forecast error variance in gross enrollment that is explained by innovations in itself and other considered endogenous variables. It shows that innovations to itself accounted for the largest percentage ranging from 76.6 percent in the first period to 39.0 percent in the tenth period. In addition, apart from variation explained by own shocks, shocks to labour force dynamics contributed significantly to the forecast error variance in gross enrollment which grew progressively from 7.9 percent in the first period to 23.8 percent in the tenth period. The proportional contribution of economic support ratio was also large ranging from 1.8 percent in the first period to 16.9 percent in the tenth period. The fourth largest source of variation in gross enrollment appears to be from population growth rate. It accounts for approximately 12.5 percent in the first period and started to decline slightly to 10.7 percent in the tenth period.

\section{Post-Estimation Diagnostic Tests}

Having estimated the VAR model (15), the study employed various measures to the test the validity and robustness of the VAR model. First, in testing the stability conditions of the model, the study employed the graphical root characteristic polynomial. The results obtained revealed that all the roots of the characteristic polynomial for the model were inside the unit circle signifying that the defined VAR model was stable as depicted in figure 3 in Appendix I. This finding showed that the VAR model satisfy the stability conditions. Afterwards, VAR residual serial correlation Lagrangian Multiplier (LM) test to check serial correlation problem. This was followed by Jarque-Bera (JB) test to check normality. Finally, White's heteroskedasticity test with no 
cross terms for observing the variance constancy of the residuals was applied. The Diagnostic test results are shown in Appendix II. As shown in table 9 in Appendix II, there is no evidence that reveals the presence of autocorrelation at the third through to the tenth lags. In the table the P-values, which are greater than $5 \%$ level of significance, indicates that the null hypothesis of no serial correlation at lag 3 to lag 10 cannot be rejected. To test for normality, we checked the Skewness and the Kurtosis of the residuals of the model using Cholesky (Lutkepohl) Orthogonalization and Jarque-Bera normality test. The result is presented in the table 10 in Appendix II. Jarque-Bera normality test showed that the model is normally distributed with the probability value of 0.57 percent signifying that the errors are normally distributed. Finally, on heteroskedasticity test, the result in table 10 in Appendix II submits that there is no problem of heteroskedasticity in residuals. These tests indicate that the model specifications used in the VARs estimation are appropriate.

\section{Conclusion and Policy Implications}

Over the past three decades, the macro-economic implications of an upsurge in labour force on economic growth has been widely discussed and the inherent beneficial effect has become known as demographic dividend. However, the exact mechanisms linking the dividend to growth is still a subject of controversy in demography and population economics discourse. While some studies lent credence to the conventional demographic dividend paradigm which views decline in fertility as an exogenous trigger for an increasing proportion of the labour force, which under certain circumstances will lead to higher productivity and faster growth, however, some others lent credence to the education-triggered dividend model which ascribes to education the twin roles of helping to lessen fertility and expanding productivity. This motivates the current study to investigate empirically the dividend-growth nexus in the context of Nigerian economy in a multivariate VAR model spanning between the period 1970 and 2017. Specifically, the paper attempted to answer the question: Is the Nigerian Demographic Dividend an Education Dividend? Innovation Accounting Techniques was applied to assess the dynamic interactions among the variables. The empirical evidence obtained revealed that the innovation in gross enrollment made much contribution to the variation in economic growth relative to innovation in economic support ratio. The magnitude ranges between 20.09 and 27.54 percent. In essence, gross enrollment has a greater impact on economic growth than economic support ratio. The study, thus, lend credence to the theoretical view of the education-triggered dividend model which imputes to education the dual role of helping to bring down fertility and augmenting productivity. Hence, in view of these findings, thus, the study recommends that as Nigeria is aspiring to be among the 20 leading economies in the world by the year 2020 , more importantly, as the global economy shifts towards more knowledge-based sectors, investment in human capital formation need to be accorded high priority because a country's competitiveness in the New International Economic Order (NIEO) is strongly connected to the quality of her labour force.

\section{References}

Adawo, M. A., Essien, E. B., \& Ekpo, N. U. (2012). Is Nigeria's unemployment problem unsolvable? Current Research Journal of Social Sciences, 4(6), 389-395.

Agunwamba, A; Bloom, D; Friedman, A; Ozolins, M; Rosenberg, L; Steven, D; \& Weston, M. (2009). Nigeria: The Next Generation-Literature Review. Prepared for the Nigeria: The Next Generation Project, funded by the British Council Nigeria.

Aidi, H. O., Emecheta, C., \& Ngwudiobu, I. M. (2016). Population and Economic growth in Nigeria: Is there an empirical evidence of causality. International J.Advances in Social Science and Humanities, 4(2), 59-66.

Akbari, N., Esfahani, R. D., \& Jouzaryan, F. (2012). The analysis of short run and long run effects of social capital on the economic growth in Iran. Economics \& Finance Review, 1(11).

Alao, A. (2010). The politics and socio-economic dynamics of demography in Nigeria: The past and present in the future. Background paper for Nigeria: The Next Generation project.

Ali, M., Egbetokun, A., \& Memon, M. H. (2018). Human capital, social capabilities and economic growth. Economies, 6(1), 2.

Alimi, S. R., \& Ofonyelu, C. C. (2013). Toda-Yamamoto causality test between money market interest rate and expected inflation: The Fisher hypothesis revisited. European Scientific Journal, ESJ, 9(7).

Andersson, B. (2001). Scandinavian evidence on growth and age structure. Regional Studies, 35(5), 377-390.

Arabi, K. A. M., \& Abdalla, S. Z. S. (2013). The impact of human capital on economic growth: Empirical evidence from Sudan. Research in World Economy, 4(2), 43.

Asmah, E. E. (2013). Sources of Real Exchange Rate Fluctuations in Ghana. American Journal of Economics, 
3(6), 291-302.

Babatunde, M. A., \& Adefabi, R. A. (2005). Long run relationship between education and economic growth in Nigeria: Evidence from the Johansen's cointegration approach. In regional conference on education in West Africa: Constraints and opportunities Dakar, Senegal.

Bakare, A. S. (2006). The Growth Implication of Human Capital Investment in Nigeria: An Empirical Study. Journal of Economics and Social Studies, 5, 110-125.

Barro, R. J. (1991). Economic growth in a cross section of countries. The quarterly j. of eco., 106(2), 407-443.

Barro, R. J., \& Lee, J. W. (1994). Sources of economic growth. In Carnegie-Rochester conference series on public policy (Vol. 40, pp. 1-46). North-Holland.

Barro, R. J., \& Sala-i-Martin, X. (1995). Technological diffusion, convergence, and growth (No. w5151). National Bureau of Economic Research.

Behrman, J., Duryea, S., \& Székely, M. (1999). Aging and economic opportunities: Major world regions around the turn of the century.

Bloom, D. E., \& Canning, D. (2004). Global demographic change: Dimensions and economic significance (No. w10817). National Bureau of Economic Research.

Bloom, D. E., \& Williamson, J. G. (1998). Demographic transitions and economic miracles in emerging Asia. The World Bank Economic Review, 12(3), 419-455.

Bloom, D. E., Humair, S., Rosenberg, L., Sevilla, J. P., \& Trussell, J. (2013). A Demographic Dividend for Sub-Saharan Africa: Source, Magnitude, and Realization (= IZA Discussion Paper, No. 7855).

Bloom, D., Canning, D., \& Sevilla, J. (2003). The demographic dividend: A new perspective on the economic consequences of population change. Rand Corporation.

Bloom, D., Finlay, J., Humair, S., Mason, A., Olaniyan, O., \& Soyibo, A. (2010). Prospects for economic growth in Nigeria: A demographic perspective. In IUSSP Seminar on Demographics and Macroeconomic Performance, Paris, France.

Bongaarts, J. (2010). The causes of educational differences in fertility in Sub-Saharan Africa. Vienna yearbook of population research, 31-50.

Brandsma, A. Kancs d'A., (2010), Rhomolo: A New dynamic general equilibrium Framework for evaluating the EU regional policies,[w]: Tiruneh M., Radvansky M. (red.), 2010, Regional disparities in Central and Eastern Europe. In Conference proceedings, Institute of Economic Research, Slovakia.

Braun, P. A., \& Mittnik, S. (1993). Misspecifications in vector autoregressions and their effects on impulse responses and variance decompositions. Journal of Econometrics, 59(3), 319-341.

Cass, D. (1965). Optimum growth in an aggregative model of capital accumulation. The Review of economic studies, 32(3), 233-240.

Cheung, Y. W., \& Lai, K. S. (1993). Finite-sample sizes of Johansen's likelihood ratio tests for cointegration. Oxford Bulletin of Economics and statistics, 55(3), 313-328.

Chisom, E. (2018). Population and Economic Growth in Nigeria: Is there an Empirical Evidence of Causality?. IJASSH.

Choudhry, M. T., \& Elhorst, J. P. (2010). Demographic transition and economic growth in China, India and Pakistan. Economic Systems, 34(3), 218-236.

Cochrane, S. H. (1979). Fertility and Education. What do we really know? Baltimore, Maryland: Johns Hopkins University Press.

Cochrane, S. H., Khan, M. A., \& Osheba, I. K. T. (1990). Education, income, and desired fertility in Egypt: A revised perspective. Economic Development and Cultural Change, 38(2), 313-339.

Cohen, D., \& Soto, M. (2007). Growth and human capital: Good data, good results. Journal of economic growth, 12(1), 51-76.

Crespo Cuaresma, J., Lutz, W., \& Sanderson, W. C. (2012). Age Structure, Education and Economic Growth.

Cuaresma, J. C., Lutz, W., \& Sanderson, W. (2014). Is the demographic dividend an education dividend? Demography, 51(1), 299-315. 
Cutler, D. M., Poterba, J. M., Sheiner, L. M., Summers, L. H., \& Akerlof, G. A. (1990). An aging society: Opportunity or challenge? Brookings papers on economic activity, 1990(1), 1-73.

De la Fuente, A., \& Doménech, R. (2006). Human capital in growth regressions: How much difference does data quality make? Journal of the European Economic Association, 4(1), 1.

Dolado, J. J., \& Lütkepohl, H. (1996). Making Wald tests work for cointegrated VAR systems. Econometric Reviews, 15(4), 369-386.

Drummond, P., Thakoor, V. J., \& Yu, S. (2014). Africa rising: Harnessing the demographic dividend.

Eicher, T. S., \& García-Peñalosa, C. (2001). Inequality and growth: The dual role of human capital in development. Journal of Development Economics, 66(1), 173-197.

Engle, R. F., \& Granger, C. W. (1987). Co-integration and error correction: Representation, estimation, and testing. Econometrica: journal of the Econometric Society, 251-276.

Esso, J. L., \& Yaya, K. E. H. O. (2010). The savings-investment relationship: Cointegration and causality evidence from Uemoa countries. International Journal of Economics and Finance, 2(1), 174.

Fang, C., \& Wang, D. (2005). Demographic transition: Implications for growth. The China boom and its discontents, 34.

Feyrer, J. (2007). Demographics and productivity. The Review of Economics and Statistics, 89(1), 100-109.

Galor, O., \& Moav, O. (2004). From physical to human capital accumulation: Inequality and the process of development. The Review of Economic Studies, 71(4), 1001-1026.

Ghalandarzehi, K., \& Safdarie, M. (2012). Role \& Status of Educated human Recourses (Human Capital) on Economic Growth of Iran. International Journal of Business and Social Science, 3(11).

Guengant, J. P., \& Kamara, Y. (2012). How can we capitalize on the demographic dividend? Demographics at the heart of development pathways: Synthesis of studies conducted in WAEMU countries and in Ghana, Guinea, Mauritania and Nigeria.

Gyimah-Brempong, K., Paddison, O., \& Mitiku, W. (2006). Higher education and economic growth in Africa. The Journal of Development Studies, 42(3), 509-529.

Harris, R. (1995). Using Cointegration Analysis in Econometric Modelling (London, Harvester Wheatsheaf). Modelling Traded, Non-traded and Aggregate Inflation, 87.

Harris, R., \& Sollis, R. (2003). Applied time series modelling and forecasting. Wiley.

Hundie, S. K. (2014). Savings, investment and economic growth in Ethiopia: Evidence from ARDL approach to co-integration and TYDL Granger-causality tests. Journal of Economics and International Finance, 6(10), 232.

Inder, B. (1993). Estimating long-run relationships in economics: A comparison of different approaches. Journal of econometrics, 57(1-3), 53-68.

Issa, H. (2005). Human Capital Demographic Transition and Economic Growth. Journal of Economic Development, 30(2), 49.

Jajri, I., \& Ismail, R. (2010). Impact of labour quality on labour productivity and economic growth. African Journal of Business Management, 4(4), 486.

Johansen, S. (1992). Cointegration in partial systems and the efficiency of single-equation analysis. Journal of econometrics, 52(3), 389-402.

Johansen, S., \& Juselius, K. (1990). Maximum likelihood estimation and inference on cointegration-with applications to the demand for money. Oxford Bulletin of Economics and statistics, 52(2), 169-210.

Kamungoma-Dada, I. (2007). Why youth and youth now- the Demographic Dividend? A Roundtable discussion Human Sciences Research council, Pretoria.

Kelley, A. C., \& Schmidt, R. M. (2005). Evolution of recent economic-demographic modeling: A synthesis. Journal of Population Economics, 18(2), 275-300.

Kobzev Kotásková, S., Procházka, P., Smutka, L., Maitah, M., Kuzmenko, E., Kopecká, M., \& Hönig, V. (2018). The Impact of Education on Economic Growth: The Case of India. Acta Universitatis Agriculturae et Silviculturae Mendelianae Brunensis, 66(1), 253-262. 
Koopmans, T. C. (1965). On the concept of optimal economic growth.

Kruger, A. B., \& Lindahl, M. (2001). Education for growth: Why and for whom. Journal of Economic Literature, 39(4), 1101-1136.

Lucas, R. E. (1988). On the mechanics of economic development. Journal of monetary economics, 22(1), 3-42.

Lucas, R. E. (1990). Why doesn't capital flow from rich to poor countries? The American Economic Review, 80(2), 92-96.

Lütkepohl, H. (1993). Testing for causation between two variables in higher dimensional VAR models. Studies in Applied Econometrics, Physica-Verlag, Heidelberg, 75-91.

Lutz, W., Cuaresma, J. C., \& Sanderson, W. (2008). The demography of educational attainment and economic growth. Population, 25(29), 15-19.

Maestas, N., Mullen, K. J., \& Powell, D. (2016). The effect of population aging on economic growth, the labor force and productivity (No. w22452). National Bureau of Economic Research.

Malmberg, B. (1994). Age structure effects on economic growth-Swedish evidence. Scandinavian Economic History Review, 42(3), 279-295.

Mankiw, N. G., Romer, D., \& Weil, D. N. (1992). A contribution to the empirics of economic growth. The quarterly journal of economics, 107(2), 407-437.

Mariam, G. S., Tunde, E., \& Oluwakemi, O. (2011). The Challenges of Human Resource Management Practices in the Informal Sector in Nigeria. Chinese Business Review, 10(5).

Mason, A. (2005). Demographic transition and demographic dividends in developed and developing countries. In United Nations expert group meeting on social and economic implications of changing population age structures (Vol. 31).

Mason, A., Olaniyan, O., \& Soyibo, A. (2010). Population and economic progress in Nigeria. Background paper for Nigeria: The Next Generation project.

Mireku, K., Sarkodie, K., \& Poku, K. (2013). Effect of macroeconomic factors on stock prices in Ghana: A vector Error Correction Model Approach. International Journal of Academic Research in Accounting, Finance and Management Sciences, 3(2), 32-43.

Misra, R. (2017). Impact of Demographic Dividend on Economic Growth: A Study of BRICS and the EU. International Studies, 52(1-4), 99-117.

Mustafa, M., \& Selassie, H. M. (2000). Macroeconomic dynamics of income growth: Evidences from ARDL BOUND APPROACH, GMM AND DYNAMIC OLS.

National Bureau of Statistics, NBS. (2018). The Nigerian Statistical Fact Sheet on Economic \& Social Development. Abuja: NBS

Odhiambo, N. M. (2007). Supply-leading versus demand-following hypothesis: Empirical evidence from three SSA countries. African Development Review, 19(2), 257-280.

Odhiambo, N. M. (2010). Finance-investment-growth nexus in South Africa: An ARDL-bounds testing procedure. Economic Change and Restructuring, 43(3), 205-219.

Ogunniyi, M. B (2017). Human capital formation and economic growth in Nigeria: A time bound testing approach (1981-2014).

Osberg, L., \& Sharpe, A. (2001). Comparisons of Trends in GDP and Economic Well-being-the impact of Social Capital. In The Contribution of Human and Social Capital to Sustained Economic Growth and Well Being. Organization for Economic Co-operation and Development and Human Resource Development Canada.

Ozcicek, O., \& Douglas Mcmillin, W. (1999). Lag length selection in vector autoregressive models: Symmetric and asymmetric lags. Applied Economics, 31(4), 517-524.

Papakonstantinou, M. A. (2017). Understanding the Effects of Human Capital on Economic Growth. Groningen: University of Groningen, SOM Research School.

Pesaran, B., \& Pesaran, M. H. (2009). Microfit 5.0. Oxford: Oxford University Press.

Pesaran, M. H., \& Pesaran, B. (1997). Working with Microfit 4.0: Interactive econometric analysis [Windows version]. Oxford University Press. 
Pesaran, M. H., \& Shin, Y. (1995). Long-run Structural Modelling. Cambridge, Department of Applied Economics, University of Cambridge (No. 9419). DAE Working Paper

Pesaran, M. H., \& Shin, Y. (1998). An autoregressive distributed-lag modelling approach to cointegration analysis. Econometric Society Monographs, 31, 371-413.

Prskawetz, A., Fent, T., Barthel, W., Crespo-Cuaresma, J., Lindh, T., Malmberg, B., \& Halvarsson, M. (2007). The relationship between demographic change and economic growth in the EU. Report for Tender VT/2005/035.

Rajasekar, T., Deo, M., \& Ke, R. (2014). An Exploration in to the Causal Relationship between Performance Inputs and Traffic of Major Ports in India: A Panel Data Analysis. International Journal of Econometrics and Financial Management, 2(2), 72-81.

Raleva, S. (2014). Impact of labour on economic growth in Bulgaria (1991-2013). Economic Alternatives, 3, 5-14.

Reed, H. E., \& Mberu, B. U. (2014). Capitalizing on Nigeria's demographic dividend: Reaping the benefits and diminishing the burdens. Etude de la population africaine = African population studies, 27(2), 319.

Rentería, E., Souto, G., Mejía - Guevara, I., \& Patxot, C. (2016). The Effect of Education on the Demographic Dividend. Population and Development Review, 42(4), 651-671.

Romer, P. (1993). Idea gaps and object gaps in economic development. Journal of monetary economics, 32(3), 543-573.

Romer, P. M. (1990). Endogenous technological change. Journal of political Economy, 98(5, Part 2), S71-S102.

Sachs, J. D., Warner, A., Åslund, A., \& Fischer, S. (1995). Economic reform and the process of global integration. Brookings papers on economic activity, (1), 1-118.

Sarker, S., Khan, A., \& Mahmood, R. (2016). Working Age Population \& Economic Growth in Bangladesh: A Time-Series Approach. In International Multidisciplinary Conference on Sustainable Development (IMCSD) (p. 121).

Skirbekk, V., \& Samir, K. C. (2012). Fertility-reducing dynamics of women's social status and educational attainment. Asian Population Studies, 8(3), 251-264.

Thakur, V. (2012). The demographic dividend in India: Gift or curse? A state level analysis on differing age structure and its implications for India's economic growth prospects. Working paper Series 2012, 12-128. Retrieved from http://www.lse.ac.uk

Thi Nguyen, M. (2008). Dynamic Demographics and Economic Growth in Vietnam (No. 24). Development and Policies Research Center (DEPOCEN), Vietnam.

Thuku, G. K., Gachanja, P. M., \& Obere, A. (2013). The impact of population change on economic growth in Kenya.

Toda, H. Y., \& Phillips, P. C. (1993). Vector autoregressions and causality. Econometrica: Journal of the Econometric Society, 1367-1393.

Toda, H. Y., \& Phillips, P. C. (1994). Vector autoregression and causality: A theoretical overview and simulation study. Econometric reviews, 13(2), 259-285.

Toda, H. Y., \& Yamamoto, T. (1995). Statistical inference in vector autoregressions with possibly integrated processes. Journal of econometrics, 66(1), 225-250.

Van Der Ven, R., \& Smits, J. (2011). The Demographic Window of Opportunity: Age structure and sub-national economic growth in developing countries. Nijmegen Center for Economics (NICE), Institute for Management Research, 11-102.

Wei, Z., \& Hao, R. (2010). Demographic structure and economic growth: Evidence from China. Journal of Comparative Economics, 38(4), 472-491.

World Bank. (2017). World Development Indicators 2017. New York, World Bank.

Yue, Y. (2010). An econometric estimation of import demand function for Cote D'Ivoire. International Journal of Business and Management, 5(2), 77.

Zhang, H., Zhang, H., \& Zhang, J. (2015). Demographic age structure and economic development: Evidence from Chinese provinces. Journal of Comparative Economics, 43(1), 170-185. 


\section{Appendix I}

Figure 1. Channels of First Demographic Dividend

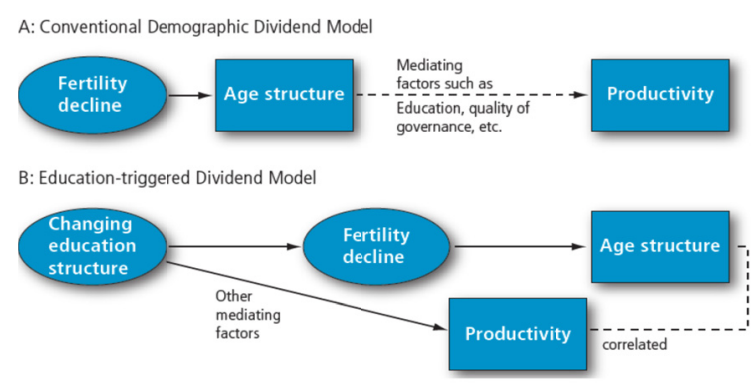

Source: Prskawetz (2014)

Figure 2. Impulse Response Functions: DLNPCR TO DLNPCR, DLNWAP, LNESR AND LNGER

Response to Cholesky One S.D. Innovations \pm 2 S.E.

Response of DLNPCR to DLNPCR

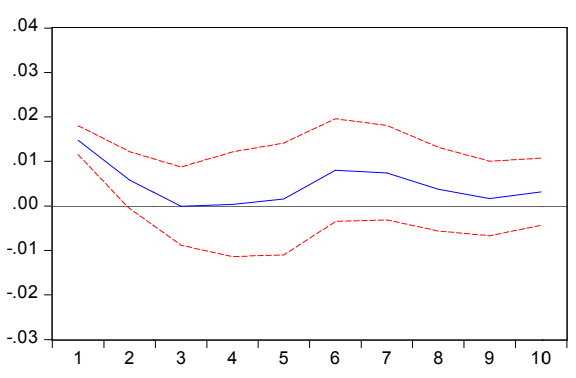

Response of DLNPCR to LNESR

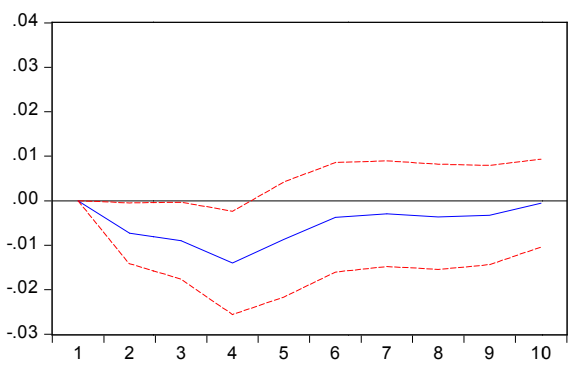

Response of DLNPCR to DLNWAP

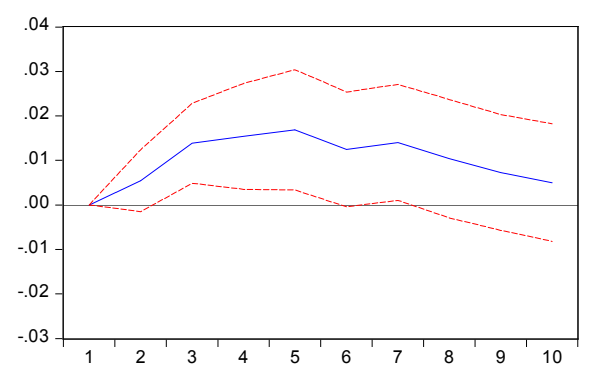

Response of DLNPCR to LNGER

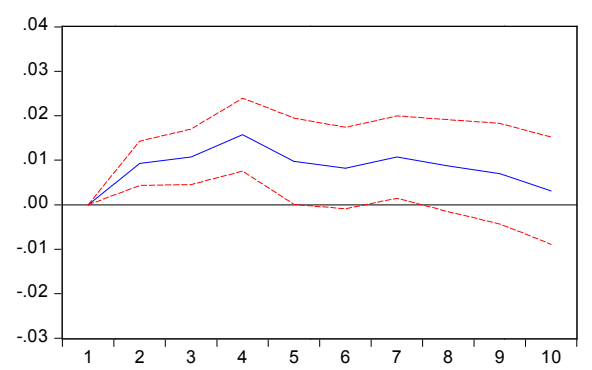

Source: Author's computation using E-view 9 (2018)

Figure 3. Inverse Roots of AR Characteristic Polynomial of VAR Model for objective three Inverse Roots of AR Characteristic Polynomial

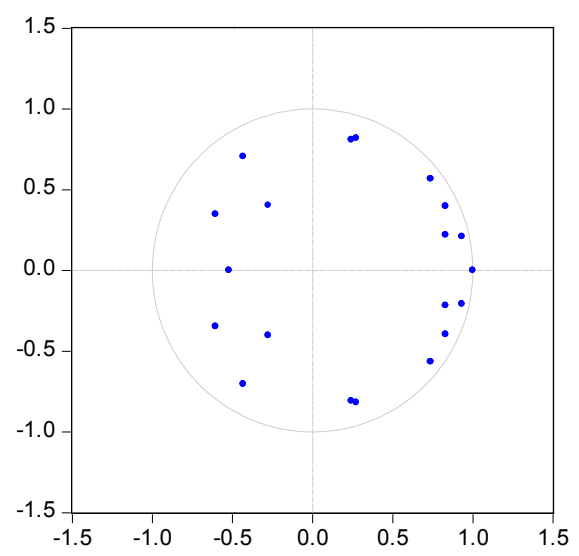

Source: Author's computation using E-view 9 (2018) 


\section{Appendix II}

Table 1. Result for the Augmented Dickey-Fuller Unit Root Test

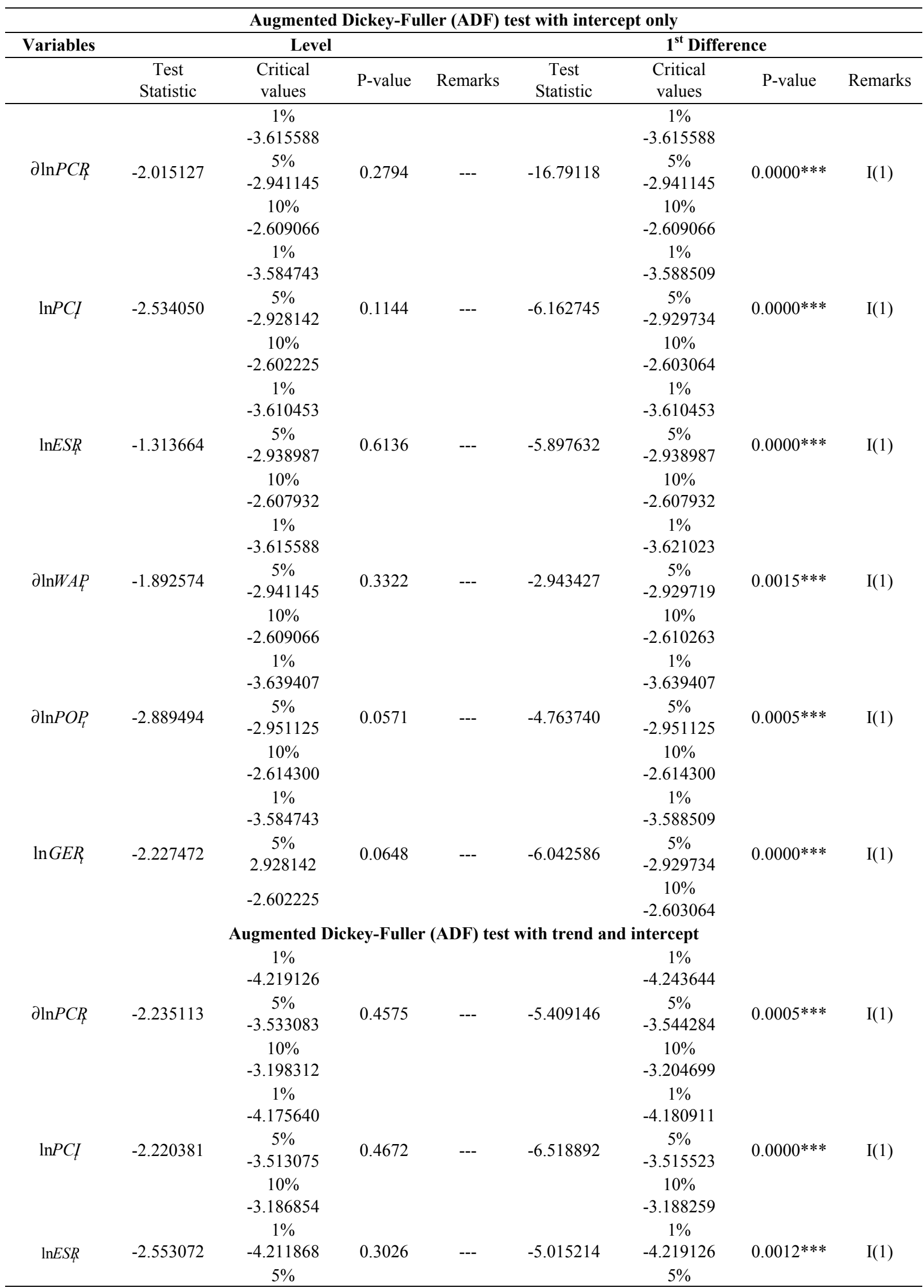




\begin{tabular}{|c|c|c|c|c|c|c|c|c|}
\hline \multirow{8}{*}{$\partial \ln W A P$} & \multicolumn{3}{|c|}{-3.529758} & \multicolumn{5}{|c|}{-3.533083} \\
\hline & \multicolumn{3}{|c|}{$10 \%$} & \multicolumn{5}{|c|}{$10 \%$} \\
\hline & \multicolumn{3}{|c|}{-3.196411} & \multicolumn{5}{|c|}{-3.198312} \\
\hline & \multicolumn{3}{|c|}{$1 \%$} & \multicolumn{5}{|c|}{$1 \%$} \\
\hline & \multicolumn{3}{|c|}{-4.211868} & \multicolumn{5}{|c|}{-4.211868} \\
\hline & \multirow[t]{3}{*}{-2.073743} & $\begin{array}{c}5 \% \\
-3.529758\end{array}$ & 0.5489 & \multirow[t]{3}{*}{---} & \multirow[t]{3}{*}{-3.779892} & $\begin{array}{c}5 \% \\
-3.529758\end{array}$ & \multirow[t]{3}{*}{$0.0285 * * *$} & \multirow[t]{3}{*}{$\mathrm{I}(1)$} \\
\hline & & $10 \%$ & & & & $10 \%$ & & \\
\hline & & -3.196411 & & & & -3.196411 & & \\
\hline \multirow{5}{*}{$\partial \ln P O P_{t}$} & \multirow{5}{*}{2.491339} & $1 \%$ & & \multirow{5}{*}{--- } & \multirow{5}{*}{-7.955861} & $1 \%$ & \multirow{5}{*}{$0.0000 * * *$} & \multirow{5}{*}{$\mathrm{I}(1)$} \\
\hline & & -4.252879 & & & & -4.252879 & & \\
\hline & & $\begin{array}{c}5 \% \\
-3.548490\end{array}$ & 1.0000 & & & $\begin{array}{c}5 \% \\
-3.548490\end{array}$ & & \\
\hline & & $10 \%$ & & & & $10 \%$ & & \\
\hline & & -3.207094 & & & & -3.207094 & & \\
\hline \multirow{5}{*}{$\ln G E R$} & \multirow{5}{*}{-3.515523} & $1 \%$ & & \multirow{5}{*}{---} & \multirow{5}{*}{-6.789065} & $1 \%$ & \multirow{5}{*}{$0.0000 * * *$} & \multirow{5}{*}{$\mathrm{I}(1)$} \\
\hline & & -4.175640 & & & & -4.180911 & & \\
\hline & & $\begin{array}{c}5 \% \\
-3.513075\end{array}$ & 0.5544 & & & $\begin{array}{c}5 \% \\
-3.515523\end{array}$ & & \\
\hline & & $10 \%$ & & & & $10 \%$ & & \\
\hline & & -3.186854 & & & & -3.188259 & & \\
\hline
\end{tabular}

Source: Author's computation using E-view 9 (2018); ***depicts that the variable is stationary at 5\%

Table 2. Result for the Philips-Peron (PP) Unit Root Test

\begin{tabular}{|c|c|c|c|c|c|c|c|c|}
\hline \multicolumn{9}{|c|}{ Philips-Peron (PP) test with intercept only } \\
\hline \multirow[t]{2}{*}{ Variables } & \multicolumn{4}{|c|}{ Level } & \multicolumn{4}{|c|}{$1^{\text {st }}$ Difference } \\
\hline & $\begin{array}{c}\text { Test } \\
\text { Statistic }\end{array}$ & $\begin{array}{l}\text { Critical } \\
\text { values }\end{array}$ & P-value & Remarks & $\begin{array}{c}\text { Test } \\
\text { Statistic }\end{array}$ & $\begin{array}{l}\text { Critical } \\
\text { values }\end{array}$ & P-value & Remarks \\
\hline$\partial \ln P C R$ & -2.240232 & $\begin{array}{c}1 \% \\
-3.584743 \\
5 \% \\
-2.928142 \\
10 \% \\
-2.602225\end{array}$ & 0.2005 & --- & -4.970063 & $\begin{array}{c}1 \% \\
-3.588509 \\
5 \% \\
-2.929734 \\
10 \% \\
-2.603064\end{array}$ & $0.0002 * * *$ & $\mathrm{I}(1)$ \\
\hline $\ln P C I$ & -2.220381 & $\begin{array}{c}1 \% \\
-3.584743 \\
5 \% \\
-2.928142 \\
10 \% \\
-2.602225\end{array}$ & 0.4672 & --- & -4.970063 & $\begin{array}{c}1 \% \\
-3.588509 \\
5 \% \\
-2.929734 \\
10 \% \\
-2.603064\end{array}$ & $0.0002 * * *$ & $\mathrm{I}(1)$ \\
\hline $\ln E S R$ & -1.633966 & $\begin{array}{c}1 \% \\
-3.588509 \\
5 \% \\
-2.929734 \\
10 \% \\
-2.603064\end{array}$ & 0.4571 & --- & -6.783329 & $\begin{array}{c}1 \% \\
-3.592462 \\
5 \% \\
-2.931404 \\
10 \% \\
-2.603944\end{array}$ & $0.0000 * * *$ & $\mathrm{I}(1)$ \\
\hline$\partial \ln W A P_{t}$ & -2.362273 & $\begin{array}{c}1 \% \\
-3.588509 \\
5 \% \\
-2.929734 \\
10 \% \\
-2.603064\end{array}$ & 0.1581 & --- & -12.44734 & $\begin{array}{c}1 \% \\
-3.592462 \\
5 \% \\
-2.931404 \\
10 \% \\
-2.603944\end{array}$ & $0.0000 * * *$ & $\mathrm{I}(1)$ \\
\hline$\partial \ln P O P_{t}$ & -2.412199 & $\begin{array}{c}1 \% \\
-3.592462 \\
5 \% \\
-2.931404 \\
10 \% \\
-2.603944\end{array}$ & 0.1444 & --- & -2.933158 & $\begin{array}{c}1 \% \\
-3.596616 \\
5 \% \\
-2.797614 \\
10 \% \\
-2.604867\end{array}$ & $0.0072 * * *$ & $\mathrm{I}(1)$ \\
\hline
\end{tabular}




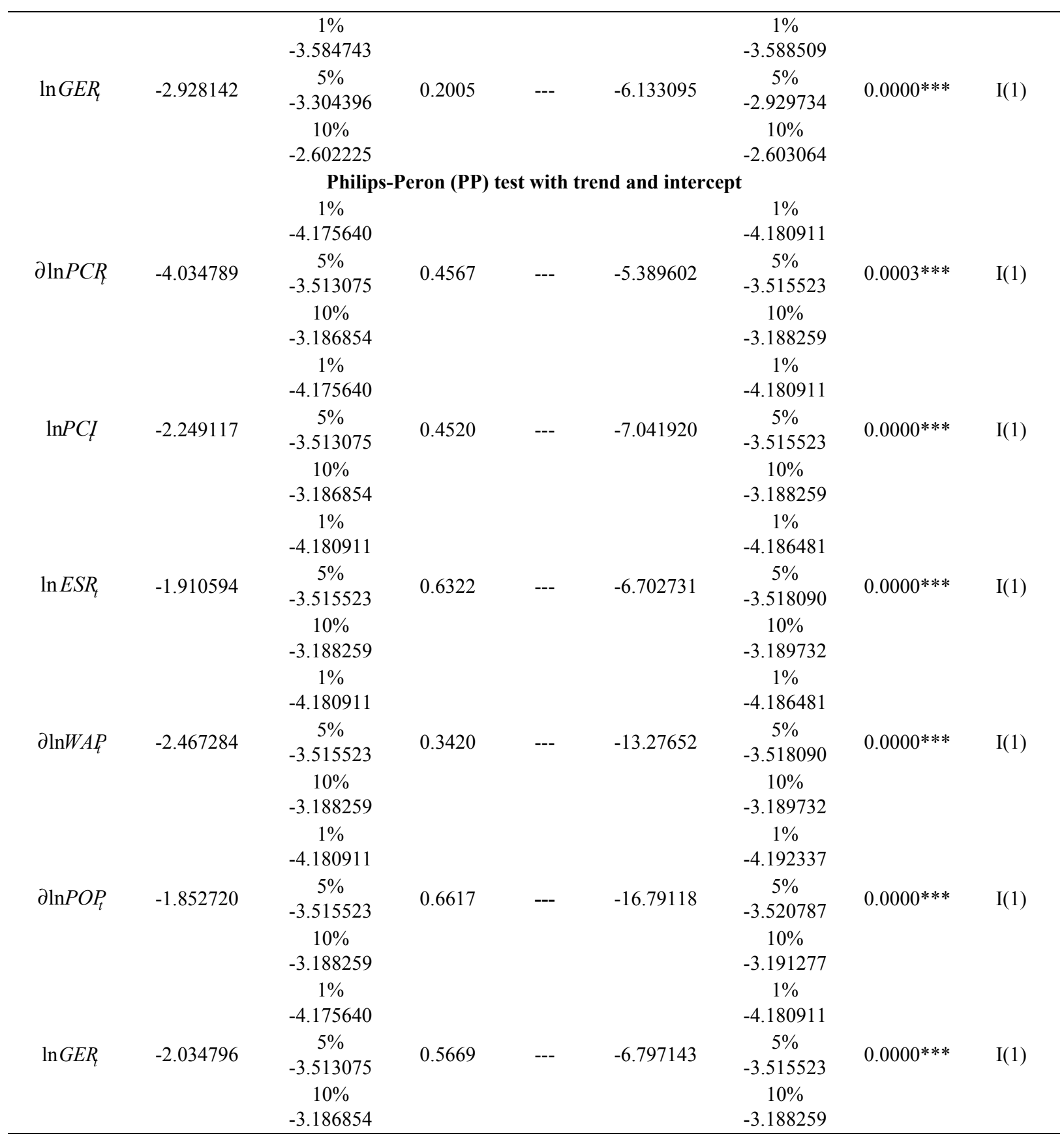

Source: Author's computation using E-view 9 (2018); $\quad * * *$ depicts that the variable is stationary at 5\%

Table 3. Optimal lag length selection criteria

\begin{tabular}{cccccc}
\hline Lag & LR & FPE & AIC & SC & HQ \\
\hline 0 & NA & $1.16 \mathrm{e}-45$ & -86.44251 & -86.19174 & -86.35119 \\
1 & 835.1996 & $1.47 \mathrm{e}-55$ & -109.2511 & -107.4957 & -108.6119 \\
2 & 253.6787 & $1.11 \mathrm{e}-58$ & -116.5550 & -113.2950 & -115.3679 \\
3 & 89.18285 & $1.54 \mathrm{e}-59$ & -118.8526 & -114.0881 & -117.1176 \\
4 & $84.99358^{*}$ & $9.09 \mathrm{e}-61^{*}$ & $-122.4086^{*}$ & $-116.1395^{*}$ & $-120.1257^{*}$ \\
\hline
\end{tabular}

* indicates lag order selected by the criterion

LR: sequential modified LR test statistic (each test at 5\% level)

FPE: Final prediction error

AIC: Akaike information criterion
SC: Schwarz information criterion

HQ: Hannan-Quinn information criterion 
Table 4. Results of Bound Test Approach to Cointegration

\begin{tabular}{cccc}
\hline \multirow{2}{*}{ Level of Significance $(\alpha \%)$} & \multicolumn{2}{c}{ Critical value } & \multirow{2}{*}{ F-calculated / Computed F-statistic } \\
\cline { 2 - 3 } & Lower bound I(0) & Upper bound I(1) & \\
\hline 10 & 2.26 & 3.35 & \multirow{2}{*}{10.40178} \\
5 & 2.62 & 3.79 & \\
2.5 & 2.96 & 4.18 & \\
1 & 3.41 & 4.68 & \\
\hline
\end{tabular}

Source: Author's computation using E-view 9 (2018)

Table 5. Granger Causality Tests based on TYDL approach

\begin{tabular}{lccc}
\hline Null Hypothesis & Chi-Square $\left(\mathrm{X}^{2}\right)$ & P-Value & Conclusion \\
\hline LNESR does not granger cause DLNRGDPPC & 16.24736 & 0.0027 & Reject Ho \\
LNGER does not granger cause DLNRGDPPC & 11.75569 & 0.0193 & Reject Ho \\
LNESR and LNGER do not jointly granger cause DLNRGDPPC & 25.97747 & 0.0005 & Reject Ho \\
DLNPOP does not granger cause LNESR & 11.58710 & 0.0207 & Reject Ho \\
DLNPOP does not granger cause DLNWAP & 10.85961 & 0.0282 & Reject Ho \\
DLNPOP does not granger cause DLNRGDPPC & 17.84307 & 0.0013 & Reject Ho \\
DLNRGDPPC does not granger cause DLNPOP & 23.14653 & 0.0001 & Reject Ho \\
DLNWAP does not granger cause DLNRGDPPC & 16.12024 & 0.0029 & Reject Ho \\
\hline
\end{tabular}

Source: Author's computation using E-view 9 (2018)

Table 6. Variance Decomposition of per capital Real GDP growth rate ( $\triangle \mathrm{LNPCR}$ )

\begin{tabular}{ccccccc}
\hline Period & S.E. & $\Delta$ LNPCR & $\Delta$ LNPOP & $\Delta$ LNWAP & LNESR & LNGER \\
\hline 1 & 0.014771 & 100.0000 & 0.000000 & 0.000000 & 0.000000 & 0.000000 \\
2 & 0.020711 & 58.69904 & 1.878955 & 6.857661 & 12.46817 & 20.09617 \\
3 & 0.029046 & 29.84596 & 4.162216 & 26.15779 & 15.94805 & 23.88599 \\
4 & 0.039785 & 15.91532 & 5.843932 & 28.94474 & 20.89998 & 28.39603 \\
5 & 0.045421 & 12.33026 & 5.576521 & 35.96802 & 19.73150 & 26.39371 \\
6 & 0.048643 & 13.47554 & 4.963208 & 37.91300 & 17.79673 & 25.85152 \\
7 & 0.052368 & 13.65027 & 4.315555 & 39.88693 & 15.66821 & 26.47903 \\
8 & 0.054361 & 13.14594 & 4.042259 & 40.65576 & 14.99265 & 27.16340 \\
9 & 0.055429 & 12.73509 & 3.966479 & 40.82607 & 14.76249 & 27.70988 \\
10 & 0.055916 & 12.83498 & 4.191580 & 40.91922 & 14.51683 & 27.53740 \\
\hline
\end{tabular}

Cholesky Ordering: $\triangle$ LNPCR $\triangle$ LNPOP $\Delta$ LNWAP LNESR LNGER

Source: Author's computation using E-view 9 (2018)

Table 7. Variance Decomposition of Labour Force Dynamics ( $\triangle$ LNWAP)

\begin{tabular}{ccccccc}
\hline Period & S.E. & $\Delta$ LNPCR & $\Delta$ LNPOP & $\Delta$ LNWAP & LNESR & LNGER \\
\hline 1 & 6.33 E-05 & 1.491100 & 1.961208 & 96.54769 & 0.000000 & 0.000000 \\
2 & 0.000212 & 19.53479 & 1.495767 & 73.39711 & 2.346612 & 3.225717 \\
3 & 0.000442 & 16.77808 & 2.991125 & 61.45741 & 3.812375 & 14.96101 \\
4 & 0.000719 & 13.81227 & 5.1463740 & 57.11322 & 5.031885 & 18.27889 \\
5 & 0.000999 & 11.16897 & 9.645018 & 53.78700 & 8.987923 & 16.41109 \\
6 & 0.001246 & 9.301332 & 11.78134 & 55.15313 & 9.975352 & 13.71884 \\
7 & 0.001439 & 9.298449 & 11.89266 & 56.49728 & 9.824561 & 12.48705 \\
8 & 0.001581 & 9.686972 & 11.25048 & 57.27895 & 9.374157 & 12.40944 \\
9 & 0.001685 & 10.01091 & 10.97814 & 57.60798 & 9.099829 & 12.30314 \\
10 & 0.001767 & 10.33107 & 11.02035 & 57.55322 & 9.094031 & 12.00134 \\
\hline
\end{tabular}

Cholesky Ordering: $\triangle$ LNPCR $\triangle$ LNPOP $\Delta$ LNWAP LNESR LNGER

Source: Author's computation using E-view 9 (2018) 
Table 8. Variance Decomposition of Economic Support Ratio (LNESR)

\begin{tabular}{ccccccc}
\hline Period & S.E. & $\Delta$ LNPCR & $\Delta$ LNPOP & $\Delta$ LNWAP & LNESR & LNGER \\
\hline 1 & 0.001084 & 2.346783 & 0.752122 & 96.88656 & 0.014535 & 0.000000 \\
2 & 0.001731 & 24.56217 & 0.299854 & 69.60271 & 1.989879 & 3.545387 \\
3 & 0.002236 & 23.54168 & 0.174543 & 56.50594 & 3.129966 & 16.64788 \\
4 & 0.002525 & 21.64547 & 0.143269 & 51.77064 & 4.054781 & 22.38585 \\
5 & 0.002808 & 19.03028 & 0.259464 & 49.85944 & 7.791696 & 23.05912 \\
6 & 0.003085 & 17.73437 & 0.271762 & 51.60007 & 9.145897 & 21.24790 \\
7 & 0.003291 & 18.94418 & 0.256177 & 50.55673 & 9.215246 & 21.02767 \\
8 & 0.003415 & 19.66058 & 0.545524 & 48.48743 & 8.948689 & 22.35778 \\
9 & 0.003467 & 19.92238 & 1.293682 & 46.80238 & 8.740687 & 23.24087 \\
10 & 0.003511 & 20.10967 & 2.136299 & 45.152908 & 8.515088 & 23.40986 \\
\hline
\end{tabular}

Cholesky Ordering: $\triangle$ LNPCR $\triangle$ LNPOP $\triangle$ LNWAP LNESR LNGER

Source: Author's computation using E-view 9 (2018)

Table 9. Variance Decomposition of Gross Enrollment (LNGER)

\begin{tabular}{ccccccc}
\hline Period & S.E. & $\Delta$ LNPCR & $\Delta$ LNPOP & $\Delta$ LNWAP & LNESR & LNGER \\
\hline 1 & 0.000573 & 1.295754 & 12.48432 & 7.898467 & 1.758934 & 76.56252 \\
2 & 0.000942 & 11.84244 & 11.01600 & 8.729683 & 11.30864 & 57.10323 \\
3 & 0.001240 & 12.75306 & 11.87911 & 7.901353 & 15.53367 & 51.93281 \\
4 & 0.001416 & 10.38579 & 12.64030 & 21.21784 & 12.47515 & 43.28091 \\
5 & 0.001566 & 9.722566 & 11.67171 & 22.07195 & 15.27724 & 41.25653 \\
6 & 0.001719 & 9.219485 & 11.17097 & 21.71088 & 16.51801 & 41.38065 \\
7 & 0.001873 & 8.755662 & 11.22979 & 22.59373 & 16.57646 & 40.84436 \\
8 & 0.001994 & 8.563446 & 11.03153 & 23.19266 & 17.47030 & 39.74206 \\
9 & 0.002061 & 8.840336 & 10.89549 & 23.74316 & 17.26046 & 39.26056 \\
10 & 0.002102 & 9.472855 & 10.73997 & 23.78644 & 16.99826 & 39.00247 \\
\hline
\end{tabular}

Cholesky Ordering: $\triangle$ LNPCR $\triangle$ LNPOP $\triangle$ LNWAP LNESR LNGER

Source: Author's computation using E-view 9 (2018)

Table 10. VAR diagnostics.

\begin{tabular}{lll}
\hline Lags & Statistic & Prob. \\
\hline Residual serial correlation tests (LM-stats.) & & 0.0371 \\
1 & 39.96403 & 0.0029 \\
2 & 48.85650 & 0.4062 \\
3 & 26.02622 & 0.8297 \\
4 & 18.29373 & 0.1866 \\
5 & 31.07270 & 0.3509 \\
6 & 29.31493 & 0.2510 \\
7 & 20.19217 & 0.7367 \\
8 & 33.27383 & 0.1244 \\
9 & 24.84378 & 0.1925 \\
10 & 30.89648 & 0.4542 \\
Residual heteroskedasticity tests (Chi-stats.) & & 0.4513 \\
Joint & 467.8497 & 0.5698 \\
Residual normality tests (Joint Chi-stats.) & & 0.5727 \\
Skewness & 4.717340 & 3.859768 \\
Kurtosis & 8.577108 & \\
Jarque-Bera & & \\
\hline
\end{tabular}

Source: Author's computation using E-view 9 (2018) 
Table 11. Data Sources and Measurements

\begin{tabular}{cccc}
\hline Variable & Description & Source & Measurement \\
\hline$\partial \ln P C R_{t}$ & Real GDP per capita growth & World Development Indicators (2018) & Rate \\
$\ln P C L_{t}$ & Growth rate of Income Per Worker & Central Bank of Nigeria Statistical Bulletin (2018) & Rate \\
$\ln E S R_{t}$ & Economic Support Ratio & World Development Indicators (2018) & $\left(\frac{L}{N}\right)$ \\
$\left(\partial \ln W A P_{t}\right)$ & Growth rate of Working Age Population & Africa Development Indicators (2018) & Rate \\
$\left(\partial \ln P O P_{t}\right)$ & Growth rate of Population & Africa Development Indicators (2018) & Rate \\
$\ln G E R_{t}$ & Human Capital Accumulation & & Penn World Table, version 9.0 \\
\hline
\end{tabular}

$E_{h}^{t}=$ Enrolment at the level of education $\mathbf{h}$ in school-year $\mathbf{t}$.

$P_{h, a}^{t}=$ Population in age-group a which officially corresponds to the level of education $\mathbf{h}$ in school-year $\mathbf{t}$.

\section{Copyrights}

Copyright for this article is retained by the author(s), with first publication rights granted to the journal.

This is an open-access article distributed under the terms and conditions of the Creative Commons Attribution license (http://creativecommons.org/licenses/by/4.0/). 